\title{
KARAKTERISTIK FASAD BANGUNAN RUMAH KOMPAK
}

\author{
Rahmatika Apriyanti \\ (Mahasiswa) Program Studi Arsitektur, Universitas Tanjungpura \\ rahmatikaapriyanti@yahoo.com
}

\author{
M. Ridha Alhamdani \\ Program Studi Arsitektur, Universitas Tanjungpura \\ mridhaalhamdani@gmail.com
}

\begin{abstract}
Abstrak
Penelitian ini dilatarbelakangi oleh sumber informasi yang sangat kurang mengenai karakteristik fasad rumah kompak yang ada di Indonesia. Sehingga tujuan dari penelitian ini adalah menganalisa karakteristik fasad pada beberapa rumah kompak yang ada di Indonesia. Rumah kompak merupakan rumah yang memiliki keselarasan antara desain rumah dan furnitur. Konsep pemanfaatan ruang pada rumah kompak adalah pemanfaatan furnitur secara maksimal karena furnitur adalah bagian dari ruang. Rumah kompak memiliki karakter khusus terutama pada tata ruang dan fasad. Fasad rumah kompak terbentuk karena pada umumnya konsep rumah kompak adalah simple dan juga dipengaruhi oleh lingkungan sekitar.
\end{abstract}

Kata kunci: karakteristik, fasad, rumah kompak

\begin{abstract}
This research is motivated by the lack of resources about the chacarteristics of compact house facade. This research is aimed to analyze the characteristics of several facades of the compact house in Indonesia. Compact house is a house which have a balance between the house and its funiture. The space allocation concept inside the compact house applied by maximazing by the furniture because it is considered as a part of the space. The compact house have a specific characteristic especially in the space arrangement and the facade. The compact house facade formed in the simple concept and influenced by the surrounding.
\end{abstract}

Keywords: characteristic, facade, compact house

\section{Pendahuluan}

Rumah merupakan kebutuhan dasar setiap manusia. Menurut Martin Heidegger dalam Akmal (2012), seorang filsuf dari Jerman, rumah tidak hanya berbentuk fisik, namun juga mengacu pada konsep psikologis bertempat tinggal.Seiring berkembangnnya zaman, terdapat solusi desain rumah tinggal terhadap pensiasatan berbagai keterbatasan yang ada pada lahan, yaitu rumah kompak.

Rumah kompak adalah sebuah rumah yang didesain kompak, yaitu adanya keselarasan antara desain rumah dan furnitur. Rumah yang disederhanakan, mulai dari desain hingga fungsi ruang. Konsep pemanfaatan ruang pada rumah kompak adalah pemanfaatan furnitur secara maksimal karena furnitur adalah bagian dari ruang. Selain ruang dan furnitur, rumah juga harus memiliki identitas yang dapat memperlihatkan karakter penghuninya. Identitas pada rumah diperlihatkan pada bagian fasad rumah. 


\section{Kajian Literatur}

Fasad merupakan elemen arsitektur terpenting yang mampu menyuarakan fungsi dan makna sebuah bangunan (Krier dalam Widaningsih, 2004). Sebagai suatu keseluruhan, fasad tersusun dari elemen tunggal, suatu kesatuan tersendiri dengan kemampuan untuk mengekspresikan diri mereka sendiri. Elemen tersebut yaitu alas, jendela, atap, dan sebagainya karena sifat alaminya merupakan benda-benda yang berbeda sehingga memiliki bentuk, warna dan bahan yang berbeda (Krier dalam Widaningsih, 2004). Ching dalam Widaningsih (2004) mengatakan bahwa: "Komponen visual yang menjadi objek transformasi dan modifikasi dari fasad bangunan dapat diamati dengan membuat klasifikasi melalui prinsip-prinsip gagasan formatif yang menekankan pada geometri, simetri, kontras, ritme, proporsi dan skala".

Menurut Ching (1979) "Perlengkapan visual bentuk yang menjadi objek transformasi dan modifikasi bentuk elemen pada fasad bangunan meliputi sosok, ukuran, warna, tekstur, posisi, orientasi dan inersia visual."Suatu dasar geometris untuk mengorganisir bentuk dan ruang dalam sebuah bangunan. Prinsip-prinsip tambahan yang bisa digunakan untuk menciptakan tatanan di dalam suatu komposisi arsitektural (Ching, 2008).

Rumah kompak adalah rumah yang disederhanakan, mulai dari desain hingga fungsi ruang. Furnitur menjadi elemen utama pada bangunan. Keberadaan furnitur mengurangi elemenelemen pengisi ruang dalam yang tidak lagi diperlukan. Sebuah kesederhanaan bentuk, pola hidup, serta efesiensi dapat dirasakan di dalamnya (Akmal, 2012)

\section{Hasil dan Pembahasan}

Pada pembahasan ini, akan dilakukan analisa terhadap objek penelitian sesuai dengan parameter penelitian. Setelah dilakukan analisa objek dengan parameter, maka akan terlihat umumnya karakteristik pada fasad rumah kompak, maka selanjutnya akan ditarik kesimpulan mengenai karakteristik fasad rumah kompak di Indonesia.

Objek penelitian yaitu fasad dari 7 rumah kompak yang ada di Indonesia. Pemilihan sample dilakukan dengan memperhatikan letak bangunan dan ukuran luas bangunan.

Objek penelitian yaitu fasad dari 7 rumah kompak yang ada di Indonesia. Pemilihan sample dilakukan dengan memperhatikan letak bangunan dan ukuran luas bangunan.

a. Wisnu's Steel House

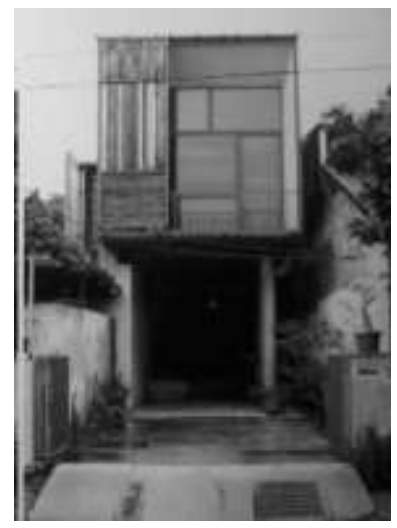

Gambar 1. Wisnu's Steel House

Sumber : Akmal, Small \& Budget House, 2012

Wisnu Steel House terletak di Bekasi. Rumah rancangan Ahmad Djuhara ini telah berdiri sejak tahun 2008 dengan luasan $215 \mathrm{~m}^{2}$. Struktur rumah menggunakan material beton yang diisi besi siku. Sedangkan penutup atap menggunakan zinc-alumunium yang relatif ringan. 

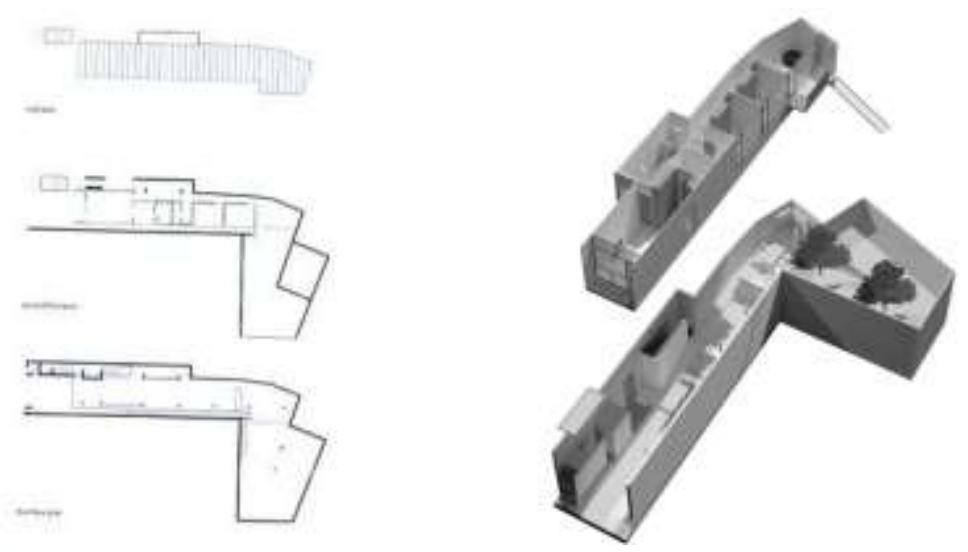

Gambar 2. Denah Wisnu's Steel House

Sumber : Akmal, Small \& Budget House, 2012

b. Multi Split House

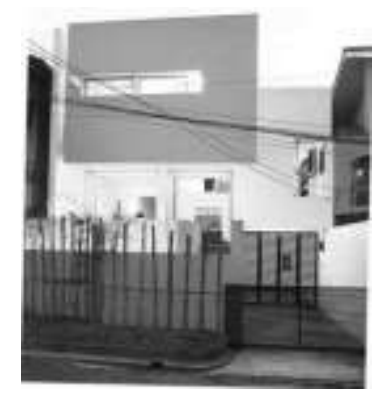

Gambar 3. Multi Split House

Sumber: Akmal, Compact House, 2012

Multi Split house terletak di Jakarta Selatan. Multi Split House dirancang oleh Wendi Djuhara. Rumah ini memiliki tiga setengah level bangunan. Lantai dasar digunakan sebagai zona servis. Lantai dua adalah zona publik, seperti : ruang serba guna, ruang makan, pantry, kamar tidur serta ruang terbuka hijau di bagian belakang yang terletak diatas dek bangunan. Lantai tiga merupakan area privat yang terdiri dari beberapa kamar, yaitu: kamar tidur utama dan satu kamar tidur anak.
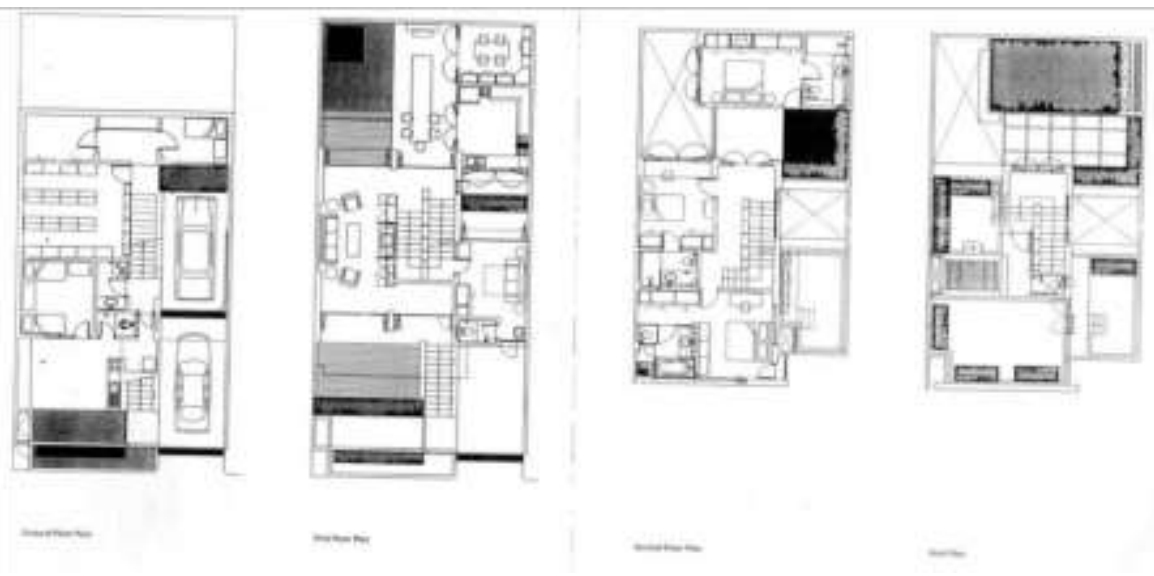

Gambar 4. Denah Multi Split House

Sumber: Akmal, Compact House, 2012 
c. 51 Sqm House

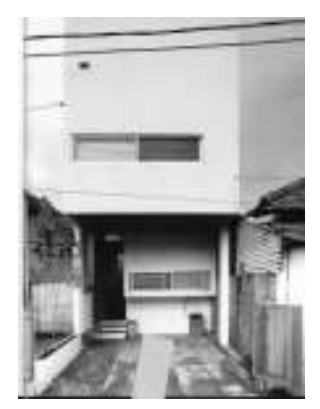

Gambar 5. 51 Sqm House

Sumber: Akmal, Compact House, 2012

51 Sqm House terletak di Jakarta Timur. Rumah karya Sontang Siregar ini memiliki luas hanya $51 \mathrm{~m}^{2}$. Rumah ini hanya mengunakan sedikit perabot yang semuanya didesain dengan tampilan yang sama. Di lantai dasar hadir sebuah dapur mungil. Pada lantai atas terdapat ruang tidur utama, ruang tidur anak dan satu buah kamar tidur tambahan. Kamar tidur anak juga berfungsi sebagai area kerja dan belajar. Terdapat sebuah bukaan 40 x $100 \mathrm{~cm}$ pada bagian belakangnya.

d. Steel House

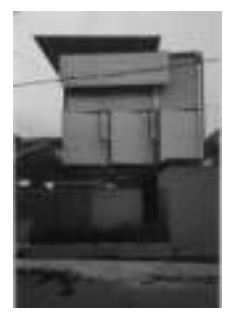

Gambar 6. Steel House

Sumber: Akmal, Small \& Budget House, 2012

Steel House terletak di Bekasi. Steel House dirancang oleh Ahmad Djuhara. Rumah tiggal ini memiliki tampilan fasad yang tidak biasa. Material keras yang identik dengan kesan industrian ini sengaja dipilih sebagai material utama. Menggunakan ukuran modul 6 x $6 \mathrm{~m}$ untuk struktur konstruksinya. Rumah ini terdiri dari 3 lantai. Lantai 1 merupakan zona publik. Area lantai 1 sengaja dibuat plong tanpa sekat demi menciptakan kesan ruang yang menyatu. Seluruh dinding menggunakan material kaca dengan bingkai kusen baja. Lantai 2 menampung ruang tidur anak, ruang keluarga, dan sebuah kamar mandi. Area lantai 3 benarbenar dimanfaatkan untuk kamar tidur utama dan kamar mandi didalamnya.
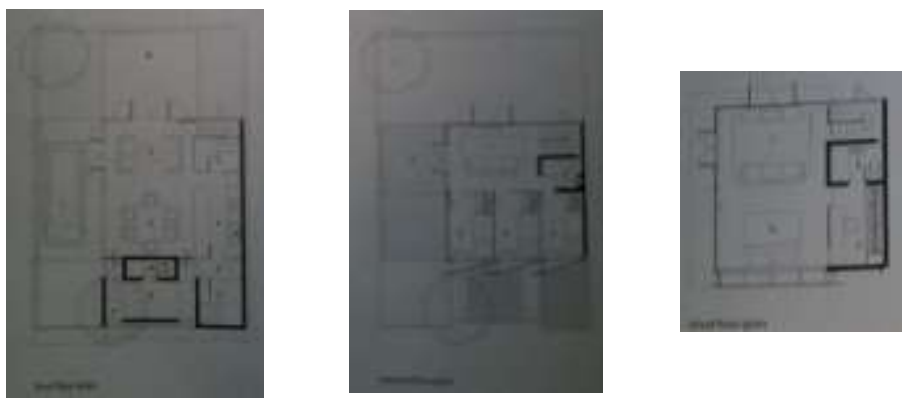

Gambar 7. Denah Muara Karang House Sumber: Akmal, Small \& Budget House, 2012 
e. Muara Karang House

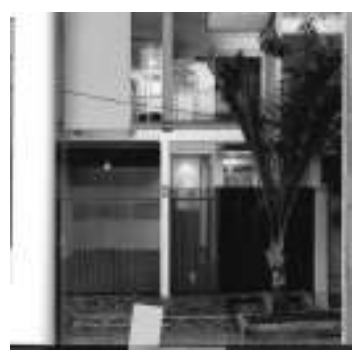

Gambar 8: Muara Karang House

Sumber: Akmal, Compact House, 2012

Muara Karang House berlokasi di Jakarta Utara. Rumah ini memiliki luas $180 \mathrm{~m}^{2}$ dan merupakan proyek renovasi. Renovasi dibantu modernspace, biro konsultan arsitek. Konsep utama yang diusung untuk proyek renovasi ini adalah meningkatkan dan memaksimalkan ruang dalam, serta menciptakan kesan ruang dalam yang lebih luas dan nyaman. Karena luas bangunan tidak begiu besar, maka modernspace menciptakan ruang penyimpanan yang menyatu dengan ruang-ruang utama. Ruang penyimpanan bawah tangga didesain sedemikian rupa sehingga terlihat menyatu dan menjadi bagian dari desain ruang dalam hunian.
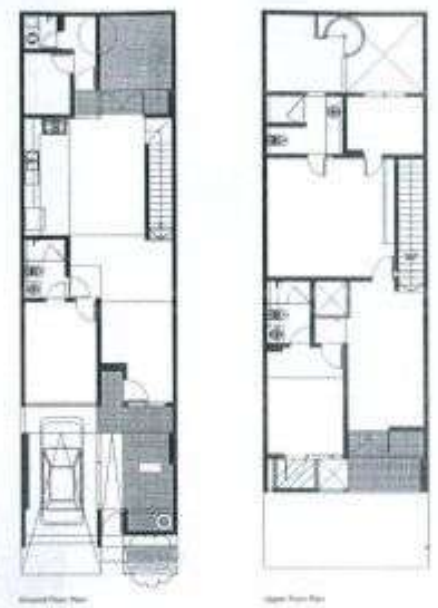

Gambar 9. Denah Muara Karang House Sumber: Akmal, Compact House, 2012

f. Manyar House

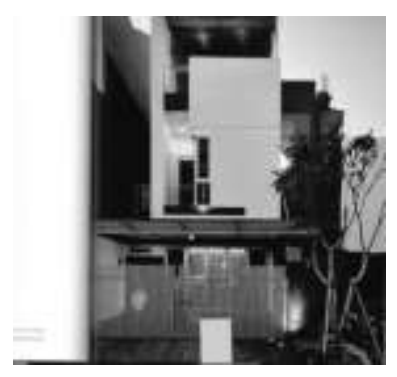

Gambar 10. Manyar House

Sumber: Akmal, Compact House, 2012 
Manyar House terletak di Jakarta Utara. Rumah ini menempati kavling 7 x 17 m dengan desain yang mengacu pada konsep perancangan ruang hunian ideal untuk masyarakat kota. Dengan konsep clean/ simple look dan bright/ airy, rumah didesain secara kompak dan ringkas namun tetap memperlihatkan kualitas penghawaan dan perancangan alami. Clean dan simple look diterapkan pada bagian dan organisasi ruang. Rumah ini memiliki 3 lantai, dimana area publik untuk hunian berupa ruang keluarga, ruang makan, dapur dan juga area servis diletakkan di lantai dasar. Area privat berupa kamar tidur dan ruang keluarga pada lantai satu serta sebuah paviliun besar berkonsep penthouse lengkap dengan walk-in closet dan kamar mandi utama serta balkon yang cuku luas di lantai teratas.

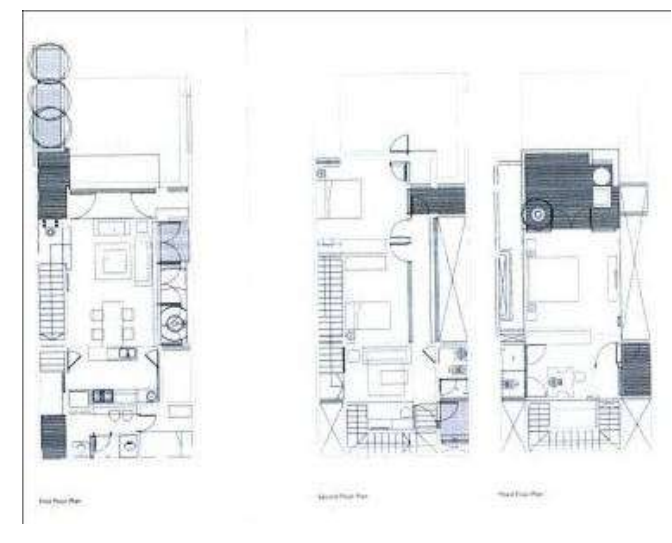

Gambar 11. Denah Manyar House

Sumber: Akmal, Compact House, 2012

g. Terrace House

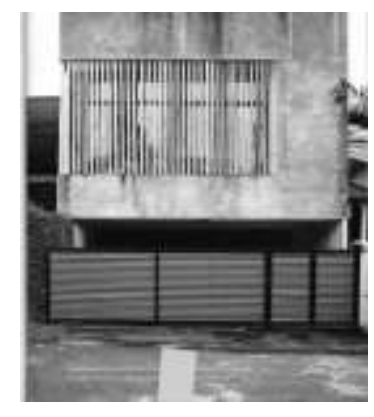

Gambar 12. Terrace House

Sumber: Akmal, Compact House, 2012

Terrace House terletak di Bintaro, Tangerang. Rumah rancangan Dwi Kurniawan ini memiliki ruang-ruang utama, seperti: ruang keluarga, ruang makan yang diletakkan menghadap ke arah danau. Pada bagian luar rumah berkesan masif, namun bagian dalamnya justru dibuat sangat terbuka, yang ditandai dengan pemakaian pintu dan jendela kaca yang berukuran besar.Pintu masuk utama pada rumah ini terletak di lantai atas, sehingga ruang utama, seperti : ruang tamu, ruang keluarga, pantry, dan kamar tidur pun di lantai atas. Pembagian ruang dalam desain secara kompak dan open plan layaknya rumah urban lainnya. Keistimewaan lain dari rumah ini adalah sebuah reflecting pool di lantai atas. 
Tabel 1 : Analisa Fasad

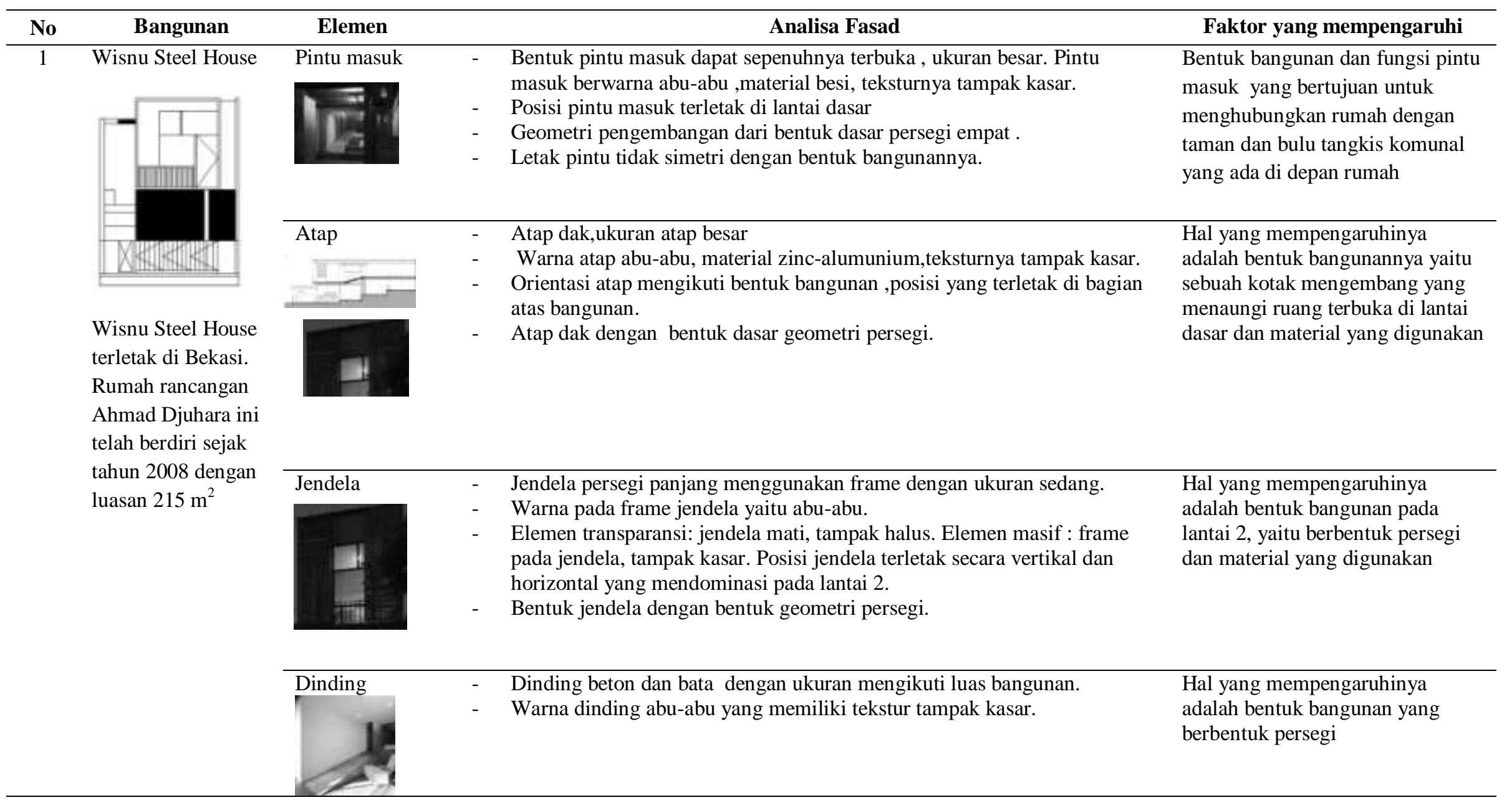




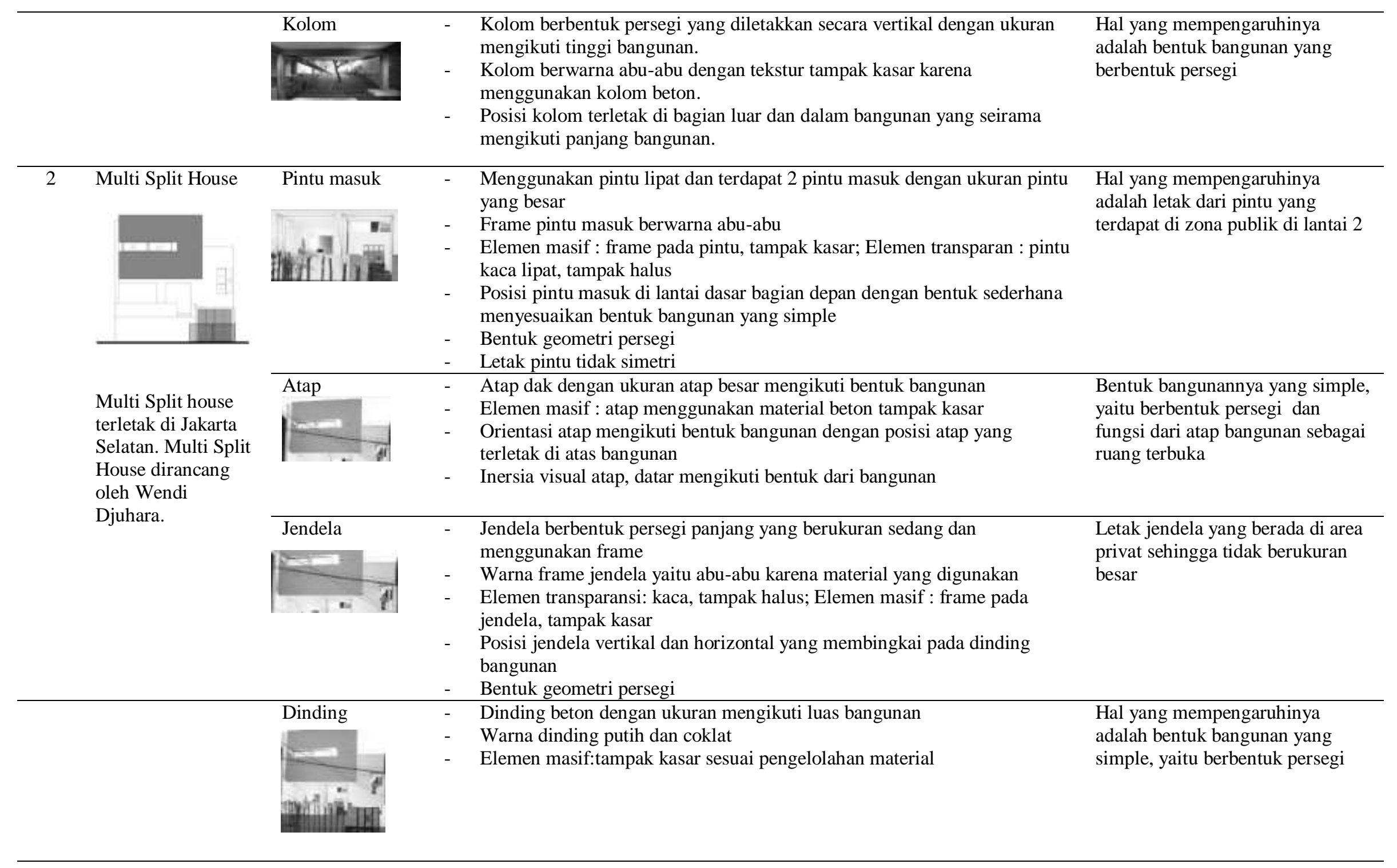




\begin{tabular}{|c|c|c|c|c|}
\hline & & Kolom & $\begin{array}{ll}\text { - } & \text { Vertikal/tegak berbentuk persegi } \\
\text { - } & \text { Kolom berwarna abu-abu } \\
\text { - } & \text { Elemen masif : kolom beton, tampak kasar } \\
\text { - } & \text { Bentuk geometri persegi }\end{array}$ & $\begin{array}{l}\text { Hal yang mempengaruhinya } \\
\text { adalah bentuk bangunan yang } \\
\text { simple, yaitu berbentuk persegi }\end{array}$ \\
\hline \multirow[t]{4}{*}{3} & 51 Sqm House & Pintu masuk & $\begin{array}{ll}\text { - } & \text { Pintu yang digunakan yaitu bentuk pintu satu daun yang berukuran kecil } \\
\text { - } & \text { Pintu masuk berwarna coklat } \\
\text { - } & \text { Elemen masif : pintu menggunakan material kayu, tampak kasar } \\
\text { - } & \text { Posisi pintu masuk dilantai dasar sebelah kiri pada bangunan dengan } \\
\text { bentuk yang sederhana menyesuaikan dengan bentuk bangunan yang } \\
\text { simple } \\
\text { - } & \text { Bentuk geometri persegi }\end{array}$ & $\begin{array}{l}\text { Bentuk bangunan yang simple dan } \\
\text { material yang digunakan }\end{array}$ \\
\hline & $\begin{array}{lr} & \\
& \\
& \\
51 \quad \text { Sqm } & \text { House } \\
\text { terletak di Jakarta } \\
\text { Timur. } & \text { Rumah } \\
\text { karya } \quad \text { Sontang } \\
\text { Siregar ini memiliki } \\
\text { luas hanya } 51 \mathrm{~m}^{2} \text {. }\end{array}$ & Atap & $\begin{array}{ll}\text { - } & \text { Atap dak yang berukuran besar mengikuti bentuk bangunan 51 Sqm } \\
& \text { House } \\
\text { - } & \text { Elemen masif : atap menggunakan material beton tampak kasar } \\
\text { - } & \text { Orientasi atap mengikuti bentuk bangunan } \\
\text { - } & \text { Posisi atap di bagian atas bangunan } \\
\text { - } & \text { Berbentuk datar mengikuti bentuk bangunan }\end{array}$ & $\begin{array}{l}\text { Bentuk bangunannya berbentuk } \\
\text { persegi dan fungsinya }\end{array}$ \\
\hline & & $d y$ & $\begin{array}{ll}\text { - } & \text { Jendela berbentuk persegi panjang dengan ukuran sedang } \\
\text { - } & \text { Frame pada jendela berwarna abu-abu } \\
\text { - } & \text { Elemen transparans:kaca, tampak halus; Elemen masif : frame pada } \\
\text { jendela,tampak kasar } \\
\text { - } \quad \text { Posisi jendela diletakkan secara horizontal yang membingkai pada dinding } \\
\text { bangunan } \\
\text { - } \quad \text { Bentuk geometri persegi }\end{array}$ & $\begin{array}{l}\text { Letak jendela yang berada di area } \\
\text { privat yaitu ruang tidur utama dan } \\
\text { letak jendela pada dapur di lantai } \\
\text { dasar }\end{array}$ \\
\hline & & Dinding & $\begin{array}{ll}- & \text { Dinding beton } \\
\text { - } & \text { Berwarna abu-abu } \\
\text { - } & \text { Elemen masif:tampak kasar sesuai pengelolahan material } \\
\text { - } & \text { Bentuk geometri persegi }\end{array}$ & $\begin{array}{l}\text { Hal yang mempengaruhinya } \\
\text { adalah bentuk bangunan yang } \\
\text { simple, yaitu berbentuk persegi }\end{array}$ \\
\hline
\end{tabular}




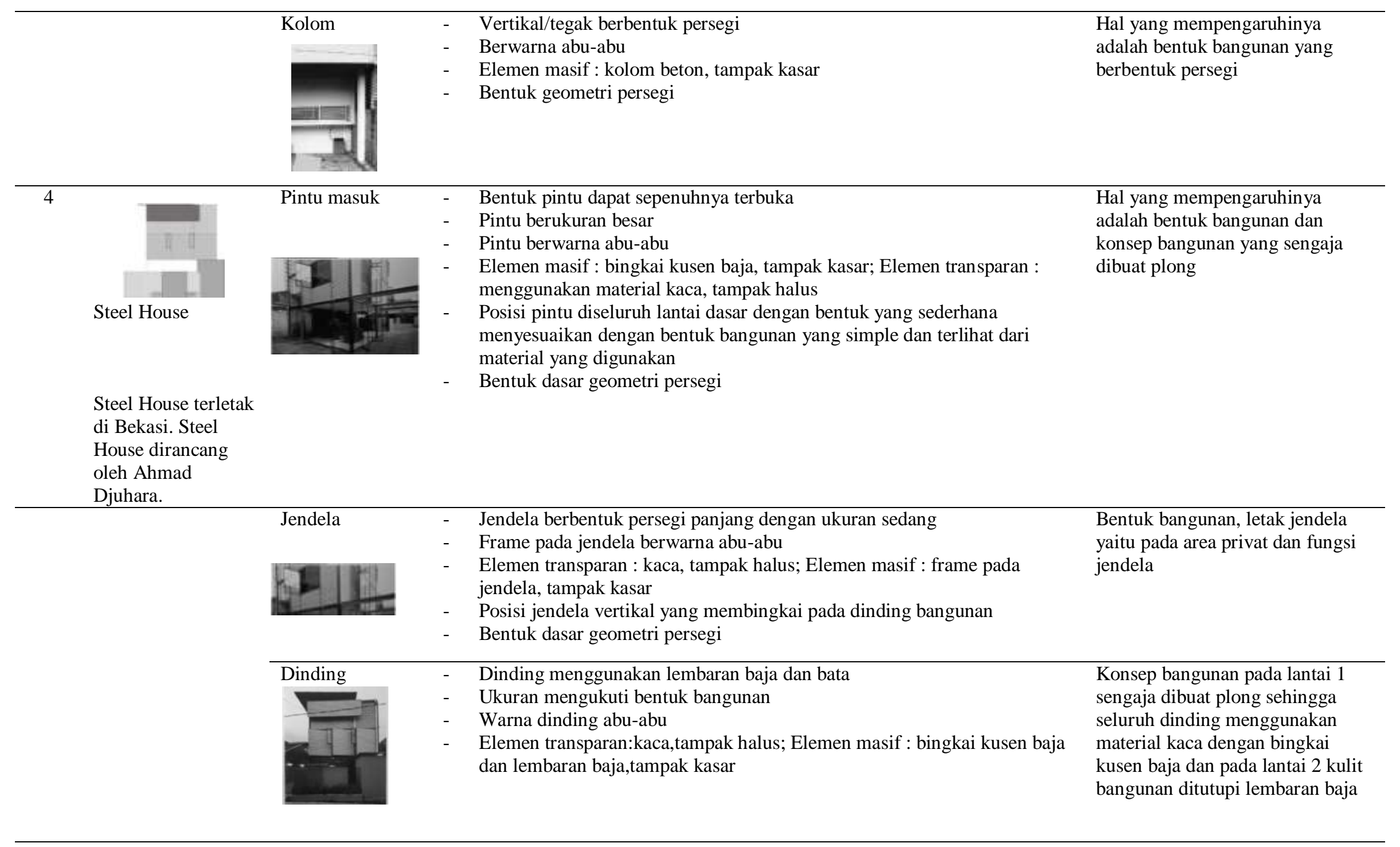




\begin{tabular}{|c|c|c|c|c|}
\hline & & Kolom & $\begin{array}{ll}- & \text { Vertikal/tegak } \\
\text { - } & \text { Struktur baja } \\
\text { - } & \text { Elemen masif, tampak kasar }\end{array}$ & $\begin{array}{l}\text { Hal yang mempengaruhinya } \\
\text { adalah bentuk bangunan,konsep } \\
\text { dan keterbatasan dana }\end{array}$ \\
\hline \multirow[t]{4}{*}{5} & $\begin{array}{l}\text { Muara Karang } \\
\text { House }\end{array}$ & \multirow[t]{2}{*}{ Pintu masuk } & \multirow[t]{2}{*}{$\begin{array}{l}\text { Terletak disebelah kanan pada bangunan, dari tampak bangunan bagian } \\
\text { depan tidak terlihat tetapi terlihat dari denah bangunan }\end{array}$} & \multirow[t]{2}{*}{$\begin{array}{l}\text { Hal yang mempengaruhinya } \\
\text { adalah bentuk bangunan } \\
\text { berbentuk persegi dan fungsi pintu } \\
\text { masuk }\end{array}$} \\
\hline & $\square$ & & & \\
\hline & \multirow[t]{2}{*}{$\begin{array}{l}\text { Muara Karang } \\
\text { House berlokasi di } \\
\text { Jakarta Utara. } \\
\text { Rumah ini memiliki } \\
\text { luas } 180 \mathrm{~m}^{2} \text { dan } \\
\text { merupakan proyek } \\
\text { renovasi }\end{array}$} & Atap & $\begin{array}{l}\text { - } \quad \text { Atap yang digunakan pada bangunan adalah atap dak dengan ukuran atap } \\
\text { besar karena mengikuti bentuk bangunan. } \\
\text { - Warna atap abu-abu sesuai dengan material yang digunakan pada atap } \\
\text { yaitu zinc-alumunium sehingga teksturnya tampak kasar. } \\
\text { - Orientasi atap mengikuti bentuk bangunan dengan posisi yang terletak di } \\
\text { bagian atas bangunan. } \\
\text { - Atap dak dengan bentuk dasar geometri persegi. }\end{array}$ & $\begin{array}{l}\text { Bentuk bangunan dari Muara } \\
\text { Karang House yang simple, yaitu } \\
\text { bentuk dasar bangunan yang } \\
\text { berbentuk persegi. }\end{array}$ \\
\hline & & Jendela & $\begin{array}{ll}\text { - } & \text { Jendela berbentuk persegi panjang dan menggunakan frame } \\
\text { - } & \text { Warna pada frame jendela yaitu abu-abu. } \\
\text { - } & \text { Elemen transparansi: material kaca, tampak halus; Elemen masif : frame } \\
\text { pada jendela, tampak kasar } \\
\text { - } \quad \text { Posisi jendela terletak secara vertikal dan horizontal yang mendominasi } \\
\text { pada lantai } 2 . \\
\text { - }\end{array}$ & $\begin{array}{l}\text { Hal yang mempengaruhinya } \\
\text { adalah bentuk bangunan } \\
\text { berbentuk persegi dan letak } \\
\text { jendela }\end{array}$ \\
\hline
\end{tabular}




\begin{tabular}{|c|c|c|c|c|}
\hline & & Dinding & $\begin{array}{ll} & \text { Dinding beton dengan ukuran mengikuti luas bangunan. } \\
\text { - } & \text { Warna dinding abu-abu yang memiliki tekstur tampak kasar. } \\
\text { - } & \text { Elemen masif:tampak kasar sesuai pengelolahan material }\end{array}$ & $\begin{array}{l}\text { Hal yang mempengaruhinya } \\
\text { adalah bentuk bangunan yang } \\
\text { simple, yaitu berbentuk persegi }\end{array}$ \\
\hline & & Kolom & $\begin{array}{ll}\text { - } & \text { Vertikal/tegak berbentuk persegi } \\
\text { - } & \text { Kolom berwarna abu-abu dengan tekstur tampak kasar karena } \\
\text { menggunakan kolom beton. }\end{array}$ & $\begin{array}{l}\text { Hal yang mempengaruhinya } \\
\text { adalah bentuk bangunan yang } \\
\text { berbentuk persegi }\end{array}$ \\
\hline \multirow[t]{3}{*}{6} & \multirow{3}{*}{$\begin{array}{l}\text { Manyar House } \\
\text { Manyar House } \\
\text { terletak di Jakarta } \\
\text { Utara. Rumah ini } \\
\text { menempati kavling } \\
7 \text { x } 17 \text { m dengan } \\
\text { desain yang } \\
\text { mengacu pada } \\
\text { konsep perancangan } \\
\text { ruang hunian ideal } \\
\text { untuk masyarakat }\end{array}$} & Pintu masuk & $\begin{array}{l}\text { Tidak terlihat dari tampak depan rumah, tetapi dapat terlihat dari denah } \\
\text { rumah }\end{array}$ & $\begin{array}{l}\text { Hal yang mempengaruhinya } \\
\text { adalah bentuk bangunan yang } \\
\text { simple, berbentuk persegi dan } \\
\text { fungsi pintu masuk }\end{array}$ \\
\hline & & Atap & $\begin{array}{l}\text { - Atap yang digunakan pada bangunan adalah atap dak dengan ukuran atap } \\
\text { besar karena mengikuti bentuk bangunan. } \\
\text { - Warna atap abu-abu sesuai dengan material yang digunakan pada atap } \\
\text { yaitu beton } \\
\text { - } \quad \text { Elemen masif : atap menggunakan material beton tampak kasar } \\
\text { - Orientasi atap mengikuti bentuk bangunan dengan posisi yang terletak di } \\
\text { bagian atas bangunan. } \\
\text { - Atap dak dengan bentuk dasar geometri persegi. }\end{array}$ & $\begin{array}{l}\text { Hal yang mempengaruhinya } \\
\text { adalah bentuk bangunannya yang } \\
\text { simple, berbentuk persegi }\end{array}$ \\
\hline & & Jendela & $\begin{array}{ll}\text { - } & \text { Jendela berbentuk persegi panjang dan menggunakan frame } \\
\text { - } & \text { Warna pada frame jendela yaitu puth } \\
\text { - } & \text { Elemen transparansi: jendela mati, tampak halus. Elemen masif : frame } \\
\text { pada jendela, tampak kasar. } \\
\text { - } \quad \text { Posisi jendela terletak secara vertikal dan horizontal yang membingkai } \\
\text { pada dinding bangunan } \\
\text { - Bentuk jendela dengan bentuk geometri persegi. }\end{array}$ & $\begin{array}{l}\text { Letak jendela yang berada di area } \\
\text { privat sehingga tidak berukuran } \\
\text { besar tetapi tetap memperlihatkan } \\
\text { kualitas penghawaan alami }\end{array}$ \\
\hline
\end{tabular}




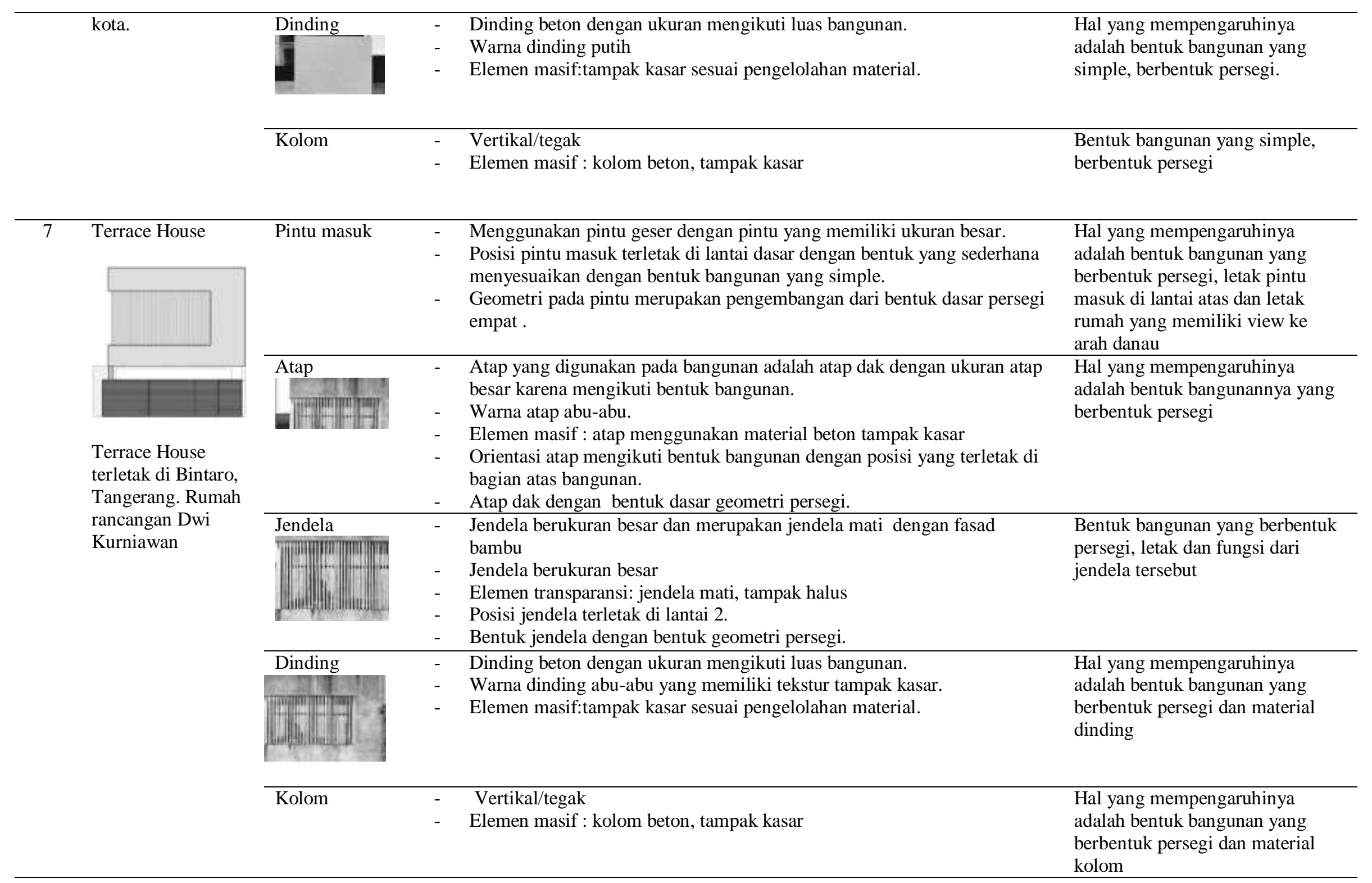




\begin{tabular}{|c|c|c|c|}
\hline \multirow{6}{*}{ Kesimpulan } & Elemen Fasad & Karakteristik Fasad & Faktor yang mempengaruhinya \\
\hline & Pintu masuk & $\begin{array}{ll}- & \text { Pintu masuk berukuran besar } \\
\text { - } & \text { Elemen transparans:kaca, tampak halus; Elemen masif : } \\
& \text { frame, tampak kasar } \\
\text { - } & \text { Posisi pintu masuk umumnya dilantai dasar } \\
\text { - } & \text { Bentuk geometri persegi }\end{array}$ & \multirow{5}{*}{$\begin{array}{ll}- & \text { Bentuk dan konsep bangunan yang } \\
\text { didesain dengan simple, yaitu terdiri } \\
\text { dari bentuk dasar persegi. } \\
\text { - } & \text { Letak elemen fasad pada bangunan } \\
\text { - } & \text { Fungsi elemen fasad pada bangunan } \\
\text { - } & \text { Material yang digunakan pada elemen } \\
\text { fasad }\end{array}$} \\
\hline & Atap & $\begin{array}{ll}- & \text { Atap dak } \\
\text { - } & \text { Ukuran atap mengikuti bentuk bangunan } \\
\text { - } & \text { Elemen masif : atap menggunakan material beton tampak } \\
& \text { kasar } \\
\text { - } & \text { Orientasi atap mengikuti bentuk bangunan dengan posisi } \\
& \text { yang terletak di bagian atas bangunan. } \\
\text { - } & \text { Atap dak dengan bentuk dasar geometri persegi. }\end{array}$ & \\
\hline & Jendela & $\begin{array}{ll}\text { - } & \text { Jendela berukuran sedang dan besar dengan menggunakan } \\
\text { frame } & \\
\text { - } & \text { Elemen transparansi: material kaca, tampak halus; Elemen } \\
\text { masif : frame pada jendela, tampak kasar } \\
\text { - } \quad \text { Posisi jendela terletak secara vertikal dan horizontal yang } \\
\text { membingkai pada dinding bangunan } \\
\text { - } \quad \text { Bentuk jendela dengan bentuk geometri persegi. }\end{array}$ & \\
\hline & Dinding & $\begin{array}{ll}\text { - } & \text { Dinding beton } \\
\text { - } & \text { Warna dinding abu-abu yang memiliki tekstur tampak } \\
& \text { kasar. } \\
\text { - } & \text { Elemen masif:tampak kasar sesuai pengelolahan material. }\end{array}$ & \\
\hline & Kolom & $\begin{array}{ll}\text { - } & \text { Vertikal/tegak } \\
\text { - } & \text { Elemen masif : kolom beton, tampak kasar }\end{array}$ & \\
\hline
\end{tabular}

Sumber: Analisis Peneliti, 2015 


\section{Kesimpulan}

Dari analisa yang telah dilakukan terhadap 7 rumah kompak yang ada di Indonesia, dapat disimpulkan bahwa karakteristik fasad atau wajah bangunan rumah kompak dengan metode menganalisa bentuk fasad dengan parameter yang telah ada.

Elemen yang pertama adalah pintu masuk. Karakteristik pintu masuk pada rumah kompak umumnya memiliki pintu masuk yang berukuran besar. Hal ini dikarenakan ingin memberikan kesan luas pada rumah. Pintu masuk umumnya menggunakan material kaca yang merupakan elemen masif sehingga tekstur dari pintu masuk tersebut tampak halus. Ada juga pintu masuk yang menggunakan material elemen masif sehingga teksturnya tampak kasar.Posisi pintu masuk pada rumah kompak umumnya berada di lantai dasar tetapi ada beberapa yang diletakkan di lantai atas. Bentuk pintu masuk menggunakan bentuk dasar geometri persegi.

Elemen yang kedua adalah atap. Karakteristik atap pada rumah kompak pada umumnya menggunakan atap dak karena atap pada rumah kompak digunakan sebagai ruang terbuka. Atap menggunakan material beton sehingga tekstur atap tampak kasar. Orientasi atap mengikuti bentuk bangunan dengan posisi atap yang diletakkan di atas bangunan. Bentuk dasar atap dak adalah geometri persegi karena bentuk bangunan yang pada umumnya berbentuk persegi.Elemen yang ketiga adalah jendela. Jendela pada rumah kompak ada yang berukuran sedang dan ada juga yang berukuran besar. Jendela berukuran sedang dipilih karena biasanya letak jendela yang berada di area privat.

Elemen selanjutnya adalah dinding. Pada umumnya dinding yang digunakan adalah dinding beton yang memiliki tekstur tampak kasar. Tapi ada juga yang manggunakan material selain beton pada dinding bangunannya, seperti baja. Elemen yang terakhir adalah kolom. Kolom diletakkan secara vertikal/tegak. Kolom yang digunakan adalah kolom beton yang memiliki tekstur tampak kasar.Faktor-faktor yang mempengaruhi semua elemen-elemen fasad pada rumah kompak adalah bentuk dan konsep rumah kompak yang pada umumnya didesain dengan simple, yang terdiri dari bentuk dasar persegi. Elemen fasad juga dipengarui oleh letak, fungsi, dan material yang digunakan pada elemen fasad tersebut.

\section{Daftar Pustaka}

Admadjaja, Jolanda Srisusana., Meydian Sartika Dewi (1999). Bab 4 Unsur Rupa Sebagai Elemen Komposisi. Gunadarma. Jakarta

Akmal, Imelda (2012). Compact House. Imaji. Jakarta

Akmal, Imelda (2012). Small \& Budget House. Imaji. Jakarta

Akmal, Imelda (2013). Tropical Modern. Imaji. Jakarta

Ching, Francis D.K (2008). Arsitektur:Bentuk,Ruang,danTatanan(EdisiKetiga). Erlangga.Jakarta

Dewi, Ni Made Emmi Nutrisia. (2014). Kajian Interior Elemen Pembentuk Dan Pelengkap Pembentuk Ruang. Program Studi Desain Interior, Sekolah Tinggi Desain Bali

Fauzy, Bachtiar., Purnama Salura., Agnes Kurnia (2013). Sintesis Langgam Arsitektur Kolonial Pada Gedung Restauran 'Hallo Surabaya' Di Surabaya . Lembaga Penelitian dan Pengabdian kepada Masyarakat, Universitas Katolik Parahyangan

Fitriyanin (....). Metode Penelitian. Universitas Komunikasi Indonesia. Bandung

Krier, Rob (2001). Komposisi Arsitektur. Erlangga. Jakarta

Pujantara, Ruly (2010). Karakteristik Fasade Bangunan Peninggalan Kolonialisme Dan Sebaran Spasialnya Di Kota Makassar

Saraswati, A.A.Ayu Oka. (2006). Bale Kulkur Sebagai Bangunan Penanda Pendukung Karakter Kota Budaya. Dosen Sejarah Arsitektur, Universitas Udayana Bali 
Utami., Mario Wibowo., Abdul Jabbar Faruk (2014). Kajian Bentuk dan Fasad Hotel Gino Feruci Bandung. Jurusan Teknik Aristektur, Fakultas Teknik Sipil \& Perencanaan, Institut Teknologi Nasional Bandung

Widaningsih, Lilis (2004). Karakteristik Fasade Bangunan Factory Outlet Di Jalan Ir. H. Djuanda Bandung. Jurusan Teknik Arsitektur. Fakultas Teknik. Universitas Pendidikan Indonesia. Bandung 